\title{
Pemodelan Dampak COVID-19 Terhadap Kebutuhan Energi di Indonesia
}

\author{
Agus Sugiyono*, Joko Santosa, Adiarso dan Edi Hilmawan \\ Pusat Pengkajian Industri Proses dan Energi (PPIPE) \\ Badan Pengkajian dan Penerapan Teknologi (BPPT) \\ Gedung 720, Klaster Inovasi dan Bisnis Teknologi, Kawasan Puspiptek \\ Kota Tangerang Selatan, Banten, Indonesia \\ *Email: agus.sugiyono@bppt.go.id
}

\begin{abstract}
In order to tackle the COVID-19 pandemic, the government issued a large-scale social restriction policy $(P S B B)$. The policy in the form of restrictions on social activities will limit economic activity which ultimately has an impact on decreasing energy demand. This PSBB policy is challenge in implementing a national energy management plan, and might causes some of the energy planning targets not to be achieved. To analyze the effect of the COVID-19 pandemic on national energy demand, an energy model was created using LEAP software. LEAP is a model for comprehensive energy planning from energy resources to energy use based on an accounting system. For the purposes of analysis, LEAP requires quite detailed data, in the form of socioeconomic data, energy data, and community activity data due to social restrictions. In this paper, the results of energy modeling simulation are discussed in terms of energy demand based on the scenario of no pandemic or bussiness as usual (BAU) and three pandemic scenarios, namely: optimistic (OPT), moderate (MOD), and pessimistic (PES) scenarios. Energy demand in 2020 is predicted to decrease by 10.7\% (OPT scenario), 15.3\% (MOD scenario), and $20.0 \%$ (PES scenario) compared to the BAU scenario. The model can still be further developed to analyze the impact, both on the overall of demand side and energy supply side and also environmental aspects.
\end{abstract}

Keywords - COVID-19, energy modeling, energy demand

\section{PENDAHULUAN}

Seiring dengan mewabahnya penyakit menular Corona Virus Disease 2019 (COVID-19), pemerintah daerah di berbagai wilayah Indonesia sejak pertengahan Maret 2020 menetapan kejadian luar biasa ataupun tanggap darurat bencana pandemi COVID-19. Pemerintah pusat pada akhirnya juga mengeluarkan Peraturan Pemerintah No. 21/2020 yang menetapkan Pembatasan Sosial Berskala Besar (PSBB) dalam Rangka Percepatan Penanganan COVID-19 pada tanggal 31 Maret 2020. Kebijakan ini kemudian diimplementasikan oleh pemerintah daerah dalam bentuk pembatasan aktivitas masyarakat. Implementasi dari kebijakan ini akan berdampak luas, mulai dari dampak sosial hingga dampak ekonomi. Di sektor energi, PSBB akan mengurangi konsumsi karena pembatasan kegiatan, seperti: perjalanan antar wilayah, operasional armada transportasi, dan kebijakan work from home (WFH) di berbagai instansi.

Kebijakan PSBB ini menjadi tantangan dalam mengimplementasikan rencana pengelolaan energi nasional yang sudah dibuat pemerintah sendiri, diantaranya yaitu: Kebijakan Energi Nasional (KEN), Rencana Umum Energi Nasional (RUEN), dan Rencana Usaha Penyediaan Tenaga Listrik (RUPTL). KEN yang tertuang dalam Peraturan Pemerintah No. 79/2014 merupakan kebijakan pengelolaan energi yang berdasarkan prinsip berkeadilan, berkelanjutan, dan berwawasan lingkungan guna terciptanya kemandirian dan ketahanan energi nasional. Salah satu target dalam KEN adalah pengembangan energi terbarukan (EBT) sebesar 23\% terhadap bauran energi primer nasional pada tahun 2025 dan meningkat menjadi $31 \%$ pada tahun 2050. Kebijakan ini ditindaklanjuti dengan dikeluarkannya RUEN yang tercantum dalam Peraturan Presiden No. 22/2017. RUEN merupakan penjabaran dan rencana pelaksanaan KEN yang bersifat lintas sektor dan dimaksud sebagai pedoman bagi instansi pemerintah dalam menyusun rencana strategis serta untuk menyusun Rencana Umum Energi Daerah (RUED) bagi pemerintah provinsi. Untuk sektor ketenagalistrikan, pemerintah sudah menetapkan RUPTL 2019-2028 melalui Keputusan Menteri Energi dan Sumber Daya Mineral No. 39 $\mathrm{K} / 20 / \mathrm{MEM} / 2019$. RUPTL memuat rencana pengembangan infrastruktur ketenagalistrikan dalam memenuhi kebutuhan listrik nasional [1]. 
Pelaksanaan PSBB yang berlangsung hingga saat ini, sudah mempengaruhi berbagai sektor ekonomi, termasuk sektor energi. Petriella [2] melaporkan bahwa pandemi COVID-19 menyebabkan penurunan konsumsi listrik karena adanya pembatasan aktivitas perkantoran, bisnis, dan industri manufaktur. Penurunan konsumsi listrik ini diperkirakan dapat mencapai 9,7\%. Setiap penurunan konsumsi listrik 1\%, diperkirakan PLN akan kehilangan pendapatan sebesar 2,8 triliun Rupiah [3]. Sehingga penurunan konsumsi listrik sebesar 9,7\%, berdampak pada kehilangan pendapatan PLN sebesar 27,16 triliun Rupiah. Oleh karena itu, untuk mengantisipasi dampak lebih luas dari pandemi COVID-19 terhadap kebutuhan dan penyediaan energi nasional perlu dilakukan analisis secara rinci melalui simulasi pemodelan energi berdasarkan berbagai skenario pandemi. Secara umum, pandemi akan mengakibatkan beberapa target yang sudah direncanakan sulit tercapai. Hasil analisis berdasarkan pemodelan energi ini dapat digunakan sebagai masukan untuk perbaikan dari perencanaan energi yang sudah disusun sebelumnya, baik di tingkat pusat maupun di tingkat daerah.

\section{METODOLOGI}

Dalam makalah ini, analisis menggunakan pemodelan energi akan difokuskan pada dampak pandemi COVID-19 terhadap kebutuhan energi di Indonesia. Pemodelan energi disusun menggunakan perangkat lunak Long-range Energy Alternative Planning (LEAP) berdasarkan studi literatur dan data sekunder. LEAP sudah banyak digunakan untuk analisis kebutuhan dan penyediaan energi serta kaitannya dengan emisi gas rumah kaca (GRK). Model yang disusun berbasis skenario terintegrasi untuk membantu perencana energi dan pembuat keputusan dalam mengidentifikasi kebutuhan dan penyediaan energi di masa depan serta dampak yang mungkin timbul dari berbagai kebijakan yang diterapkan [4][5][6]. Model energi yang dibuat merepresentasikan keseluruhan sistem energi, mulai dari sumber daya energi, proses dan konversi sampai dengan pemanfaatannya. Secara garis besar alur pikir untuk pembuatan model ditunjukkan pada Gambar 1.

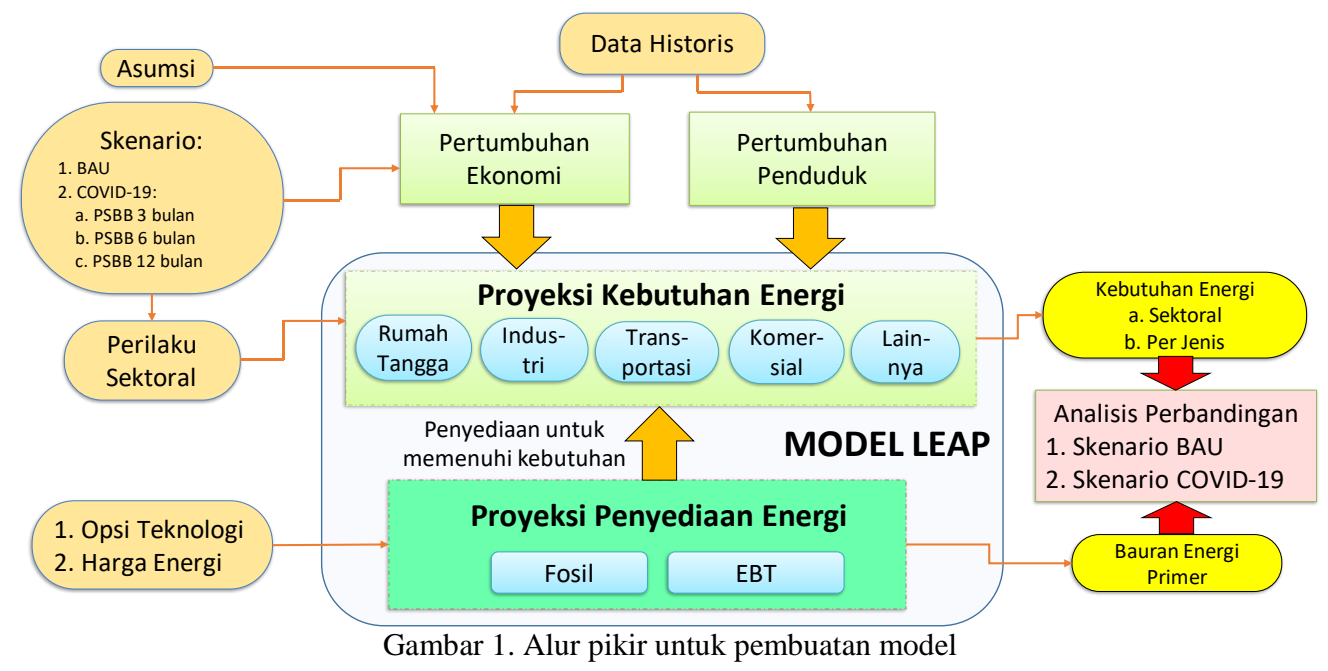

LEAP merupakan model perencanaan energi yang disusun berdasarkan sistem akuntansi. Sektor pengguna energi dibagi menjadi 5 sektor, yaitu rumah tangga, industri, transportasi, komersial, dan lainnya. Energi sebagai bahan baku untuk industri dimasukkan ke dalam sektor industri. Biomassa untuk sektor rumah tangga tidak diperhitungkan dalam model karena termasuk energi yang tidak komersial. Model menghitung kebutuhan energi untuk setiap sektor pengguna energi berdasarkan aktivitas dikalikan dengan intensitas energi. Proyeksi pertumbuhan setiap aktivitas ataupun intensitas energi merupakan variabel eksogen. Parameter masukan lainnya yang digunakan dalam model adalah data historis konsumsi energi, pertumbuhan produk domestik bruto (PDB) dan pertumbuhan penduduk. Struktur data dalam LEAP yang fleksibel memungkinkan untuk dilakukan berbagai tingkat analisis sesuai dengan rincian data yang tersedia. Perangkat lunak ini mampu melakukan simulasi dengan data yang rinci dan rumit, karena merupakan model bottom-up dengan rincian teknologi [7]. 


\section{HASIL DAN DISKUSI}

Model merupakan abstraksi dari realitas. Oleh karena itu beberapa penyederhanaan tidak dapat dihindari, dengan tetap mempertimbangkan semua aspek yang penting untuk menjawab tujuan penelitian. Beberapa asumsi juga diperlukan, mengingat data dan informasi yang tersedia di Indonesia sangat terbatas. Dalam pembuatan skenario selain asumsi juga diperlukan expert judgement. Sebagai tahun dasar model digunakan tahun 2018, karena pada tahun tersebut data-data yang terkait dengan energi sudah dipublikasi secara lengkap. Data tahun 2019-2020 diperoleh berdasarkan estimasi dengan mempertimbangkan sebagian data yang telah dipublikasi. Proyeksi dilakukan untuk setiap tahun dengan kurun waktu 2021-2025.

\section{A. Data}

Data penting yang diperlukan untuk pembuatan model adalah data energi, data sosial ekonomi, dan data aktivitas masyarakat. Data energi antara lain meliputi kebutuhan energi, penyediaan energi, dan teknologi energi. Data terkait dengan neraca energi, yang meliputi produksi, ekspor, dan impor berbagai jenis energi, baik berbasis fosil maupun energi baru terbarukan juga diinventarisasi. Sebagian besar data tersebut sudah dipublikasi oleh Kementerian ESDM [8]. Untuk data ketenagalistrikan mengacu pada publikasi PLN [9] dan Ditjen Ketenagalistrikan [10], sedangkan perencanaan ketenagalistrikan sampai tahun 2028 mengacu pada publikasi PLN [1].

Data sosial ekonomi yang penting diantaranya adalah data penduduk, PDB, dan transportasi yang ada dalam publikasi BPS [11]. Data penduduk meliputi jumlah dan kepadatan penduduk, ukuran rumah tangga, dan kelompok penduduk berdasarkan pendapatan. PDB merupakan salah satu parameter penting dalam model. Disamping nilai total PDB dalam harga konstan juga diperlukan data PDB per sektor serta nilai tambah sektor industri. Untuk transportasi dibutuhkan data seperti jumlah mobil, sepeda motor, bus, dan truk.

Data aktivitas masyarakat diperlukan terkait dengan kebijakan PSBB yang mulai diterapkan sekitar pertengahan April 2020. Selama masa PSBB di berbagai wilayah di Indonesia mengalami penurunan penjualan BBM karena mobilitas masyarakat berkurang dan karena pembatasan aktivitas sektor industri [12]. Kegiatan belajar, bekerja, dan beribadah pada prinsipnya juga harus dilaksanakan di rumah. Google [13] telah mengeluarkan data mobilitas masyarakat yang menunjukkan pergerakan orang ke tempat rekreasi, pusat perbelanjaan, tempat parkir, stasiun atau terminal, dan tempat kerja. Data menunjukkan bahwa mobilitas masyarakat mengalami penurunan yang signifikan. Penggunaan angkutan penumpang juga mengalami pembatasan karena kebijakan PSBB dan hanya angkutan barang yang boleh tetap beroperasi.

\section{B. Asumsi}

Pandemi COVID-19 menyebabkan kondisi perekonomian global mengalami kemunduran dan diperkirakan akan mengalami krisis. Berbagai lembaga keuangan memperkirakan perekonomian global akan mengalami resesi atau pertumbuhan ekonominya negatif pada tahun 2020. Kementerian Keuangan membuat koreksi pertumbuhan ekonomi Indonesia tahun 2020 berkisar antara 2,3\% sampai $-0,4 \%$ [14]. World Bank [15] mencapat bahwa pertumbuhan ekonomi Indonesia pada tahun 2019 sebesar 5\% dan memperkirakan pertumbuhan ekonomi tahun 2020 berkisar antara 2,1\% (skenario baseline) dan -3,5\% (skenario lower-case). Widyasanti [16] sudah merangkum outlook pertumbuhan ekonomi Indonesia dari berbagai instansi lain seperti Word Bank, ADB, IMF, dan Oxford Economics yang berkisar antara $-3,5 \%$ sampai 2,5\% (2020) dan meningkat menjadi 5,0\% sampai 8,5\% (2021).

Pemulihan ekonomi tergantung dari efektivitas kebijakan pemutusan sebaran virus dan kebijakan ekonomi untuk meredam dampak negatif. Pola pemulihan ekonomi akibat pandemi COVID-19 dibahas secara rinci dalam Sheiner dan Yilla [17]. Pola pemulihan ekonomi secara teoritis dapat berbentuk Z, V, U, Nike Swoosh, W, dan L. Secara ringkas penjelasan setiap pola pemulihan ekonomi dirangkum sebagai berikut (lihat Gambar 2).

- Bentuk Z digunakan untuk pemulihan ekonomi yang paling optimis. Ekonomi mengalami penurunan selama pandemi yang kemudian bangkit kembali di atas jalur pertumbuhan dan menciptakan lonjakan sementara. Secara bertahap ekonomi akan kembali ke jalur semula. 
- Bentuk V menggambarkan pola pemulihan dari guncangan ekonomi klasik yang menurun sementara dan pada akhirnya kembali menuju ke jalur pertumbuhan semula.

- Bentuk-U digunakan bila terjadi kehilangan output secara permanen setelah terjadi krisis. Ekonomi akan menurun dan membutuhkan waktu yang cukup lama untuk kembali ke jalur semula.

- Bentuk Nike Swoosh yang mirip dengan gambar logo sepatu Nike, digunakan jika terjadi penurunan tajam saat krisis dan ada dorongan untuk cepat kembali tetapi secara pelan baru dapat ke jalur pertumbuhan semula.

- Bentuk W terjadi jika setelah selesai gelombang pertama resesi muncul pandemi gelombang kedua. Sehingga pemulihan ekonomi bisa berbentuk W.

- Bentuk L menandakan terjadi kerusakan struktural perekonomian dan pertumbuhan tidak dapat kembali ke jalur pertumbuhan sebelum krisis.

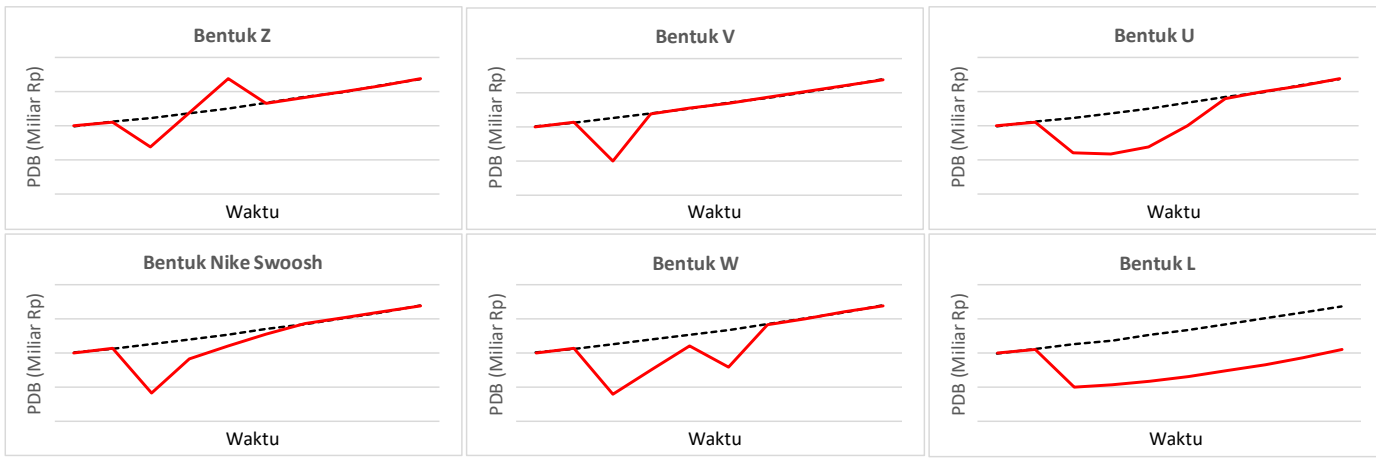

Sumber: diolah dari [17], [18], dan [19]

Gambar 2. Pola pemulihan ekonomi

Pemilihan pola pemulihan ekonomi tergantung tergantung dari durasi pembatasan sosial dan kebijakan pemulihan ekonomi untuk meredam dampak negatif. Bekkers et al [20] menggunakan tiga skenario dampak pandemi COVID-19 dalam WTO Global Trade Model dengan pemulihan berbentuk $\mathrm{V}$, U dan L. Masing-masing sesuai dengan durasi pembatasan sosial selama 3 bulan, 6 bulan dan lebih dari satu tahun.

\section{Skenario}

Pandemi COVID-19 digambarkan oleh Wahid [21] sebagai kondisi sosial masyarakat yang disebut VUCA atau volatilility (gejolak perubahan), uncertainty (ketidakpastian), complexity (kerumitan), dan ambiguity (ketidakjelasan). VUCA menggambarkan masa depan yang rumit dan penuh ketidakpastian yang harus dipertimbangkan dalam pembuatan model. Untuk menangkap kondisi tersebut dibuat serangkaian skenario yang memungkinkan untuk menganalisis dampak kebutuhan energi. Model menggunakan dua skenario utama yaitu: skenario referensi atau bussiness as usual (BAU) dan skenario penanggulangan COVID-19 dengan tiga sub-skenario yaitu optimis (OPT), moderat (MOD) dan pesimis (PES). Keseluruhan skenario ditampilkan di bawah ini (lihat Gambar 3).

- Skenario BAU merupakan kondisi bila tidak terjadi pandemi COVID-19. Pertumbuhan ekonomi pada tahun 2020 sebesar 5,05\%.

- Skenario OPT, bila kebijakan PSBB berlangsung selama 3 bulan dan penyebaran virus segera menurun. Pertumbuhan ekonomi pada tahun 2020 sebesar 2,3\%.

- Skenario MOD, bila kebijakan PSBB berlangsung selama 6 bulan dan penyebaran virus menurun secara lambat. Pertumbuhan ekonomi pada tahun 2020 sebesar $-0,4 \%$.

- Skenario PES, bila kebijakan PSBB berlangsung selama 12 bulan dan penyebaran virus berlangsung cukup lama. Pertumbuhan ekonomi pada tahun 2020 sebesar $-3,2 \%$. 


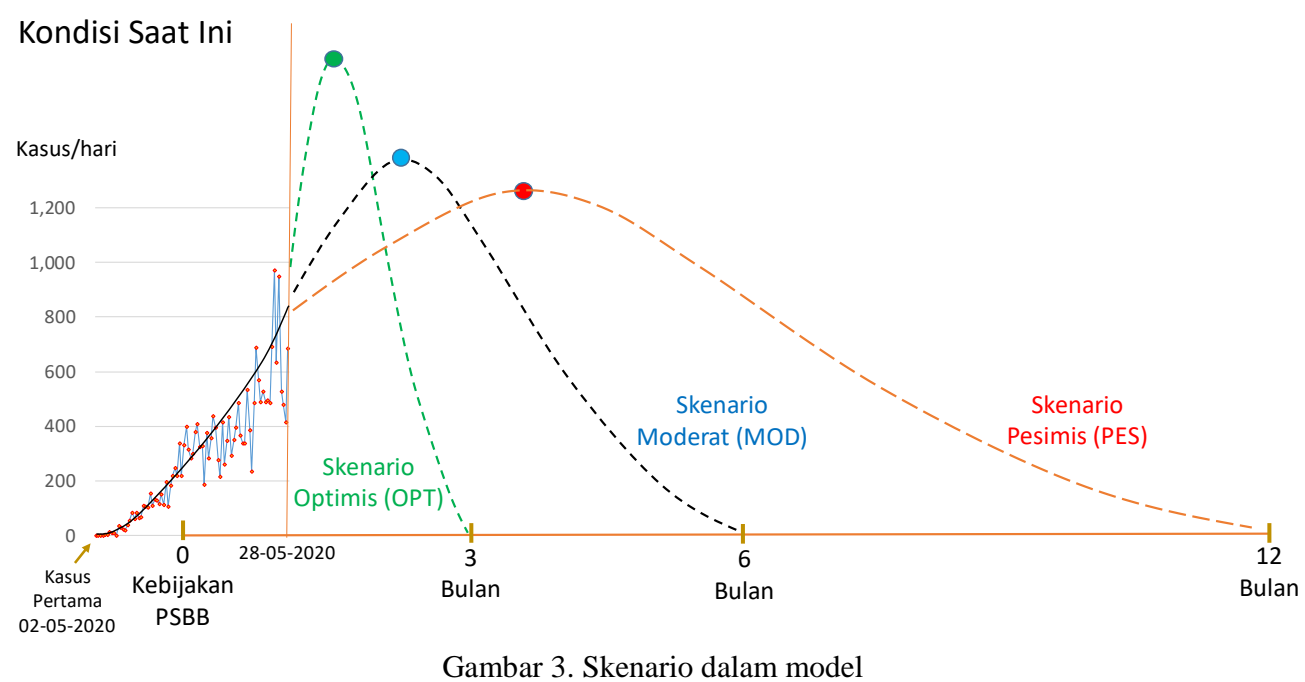

Skenario ini harus dipahami sebagai serangkaian pertanyaan ' what if' dari lama berlangsungnya PSBB terhadap kebutuhan energi, dan bukan suatu prediksi yang presisi untuk masa depan. Perbandingan skenario penanggulangan COVID-19 (OPT, MOD, dan PES) terhadap skenario BAU dapat digunakan sebagai analisis perubahan pola kebutuhan energi pada masa yang akan datang. Analisis skenario ini memungkinkan memperkirakan dampak dari pendemi COVID-19 terhadap kebutuhan energi sampai tahun 2025.

\section{Model}

Model LEAP tersusun dari empat komponen utama, yaitu: asumsi kunci (key assumption), kebutuhan energi (energy demand), transformasi energi (energy transformation) dan sumber daya (resources). Model LEAP cukup fleksibel, sehingga dapat dilakukan analisis kebutuhan energi secara terpisah. Tiga variabel kebutuhan energi yang utama adalah: aktivitas sektoral, intensitas energi, dan jenis bahan bakar atau teknologi yang digunakan. Aktivitas sektoral terkait dengan tingkat produktivitas setiap sektor. Intensitas energi merupakan jumlah penggunaan energi dibagi dengan aktivitasnya. Porsi kebutuhan energi untuk setiap sektor tergantung dari teknologi yang digunakan.

LEAP juga memungkinkan memasukkan rumus matematika untuk mengkaitkan pertumbuhan aktivitas sektoral dengan pertumbuhan PDB ataupun pertumbuhan penduduk. Faktor elastisitas yang menghubungkan pertumbuhan dua variabel dependen juga dapat dirumuskan dalam model ini. Formulasi dalam bahasa matematika ini memungkinkan untuk memprediksi ke depan yang akan berguna bagi perencana energi.

Asumsi kunci yang digunakan sebagai masukan untuk model adalah pertumbuhan penduduk dan PDB, seperti ditunjukkan pada Tabel 1. Untuk semua scenario, proyeksi pertumbuhan penduduk diasumsikan sama, sedangkan proyeksi pertumbuhan ekonomi berbeda-beda tergantung dengan lama masa PSBB dan bentuk pola pemulihan ekonomi. Proyeksi pertumbuhan ekonomi untuk skenario OPT menggunakan bentuk V, sedangkan skenario MOD dan PES menggunakan gabungan antara bentuk U dan L. 
Tabel 1. Asumsi pertumbuhan penduduk dan PDB

\begin{tabular}{|c|c|c|c|c|c|c|c|c|c|c|}
\hline & Keter & gan & 2018 & 2019 & 2020 & 2021 & 2022 & 2023 & 2024 & 2025 \\
\hline Pend & duk & $\% /$ tahun & 1,19 & 1,19 & 1,19 & 1,00 & 1,00 & 1,00 & 1,00 & 1,00 \\
\hline & & Juta jiwa & 264,7 & 267,9 & 271,1 & 273,7 & 276,5 & 279,2 & 282,0 & 284,8 \\
\hline PDB & BAU & $\% /$ tahun & 5,17 & 5,02 & 5,05 & 5,05 & 5,05 & 5,05 & 5,05 & 5,05 \\
\hline & & Triliun Rp, & 10.425 & 10.949 & 11.502 & 12.082 & 12.693 & 13.334 & 14.007 & 14.714 \\
\hline & OPT & $\% /$ tahun & 5,17 & 5,02 & 2,30 & 6,00 & 5,50 & 5,50 & 5,50 & 5,20 \\
\hline & & Triliun $\mathrm{Rp}$, & 10.425 & 10.949 & 11.201 & 11.873 & 12.526 & 13.215 & 13.941 & 14.666 \\
\hline & MOD & $\% /$ tahun & 5,17 & 5,02 & $-0,40$ & 5,00 & 6,00 & 5,50 & 5,50 & 5,20 \\
\hline & & Triliun Rp, & 10.425 & 10.949 & 10.905 & 11.450 & 12.137 & 12.805 & 13.509 & 14.211 \\
\hline & PES & $\% /$ tahun & 5,17 & 5,02 & $-3,50$ & 2,50 & 5,00 & 6,00 & 5,50 & 5,20 \\
\hline & & Triliun Rp, & 10.425 & 10.949 & 10.566 & 10.830 & 11.371 & 12.053 & 12.716 & 13.378 \\
\hline
\end{tabular}

Pembatasan aktivitas masyarakat karena pandemi COVID-19, menyebabkan aktivitas untuk berbagai sektor pengguna energi mengalami perubahan, jika dibandingkan dengan skenario BAU. Aktivitas sektor pengguna energi ini merupakan parameter yang dimasukkan dalam model sesuai dengan skenario yang disusun. Sebagian besar aktivitas untuk skenario OPT, MOD, dan PES akan menurun bila dibandingkan skenario BAU, kecuali sektor rumah tangga yang aktivitasnya meningkat. Parameter aktivitas yang dimasukkan dalam model ditunjukkan pada Gambar 4.

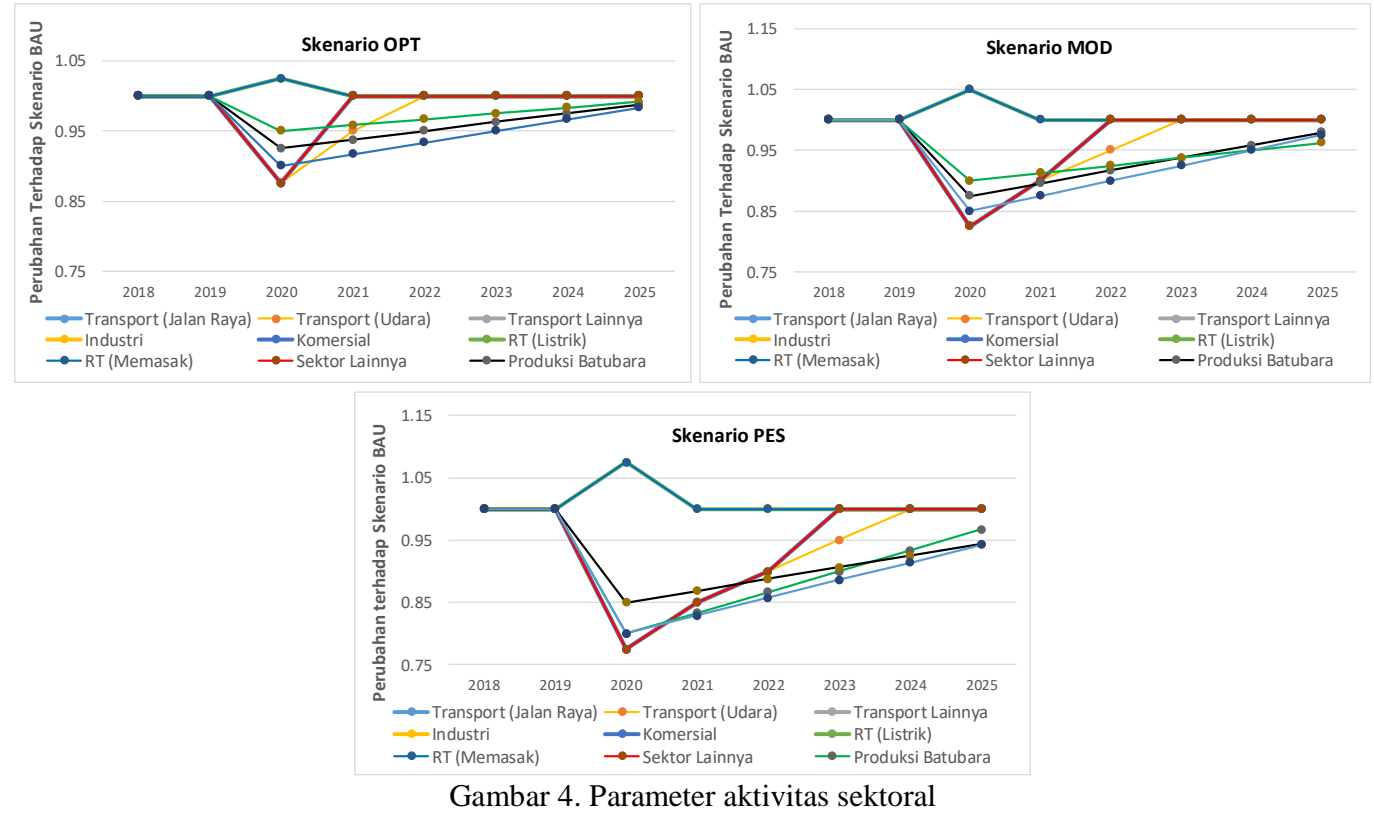

\section{E. Proyeksi Kebutuhan Energi}

Hasil perhitungan model untuk kebutuhan energi sektoral dari setiap scenario ditunjukkan pada Gambar 5. Dari gambar dapat dilihat bahwa kebutuhan energi di Indonesia pada tahun 2018 mencapai 939 juta setara barel minyak (SBM) dengan pangsa terbesar digunakan di sektor transportasi $(42 \%)$ dan diikuti sektor industri (38\%), rumah tangga (13\%), komersial (5\%), dan sisanya sektor lainnya (2\%). Selama kurun waktu 2018-2025 kebutuhan energi untuk skenario BAU meningkat dari 939 juta SBM menjadi 1.198 juta SBM atau meningkat sebesar 3,5\% per tahun. Pertumbuhan kebutuhan energi di sektor komersial paling tinggi dibandingkan sektor-sektor lain yaitu sebesar $6,1 \%$ per tahun, diikuti oleh sektor rumah tangga sebesar $4,4 \%$ per tahun. 


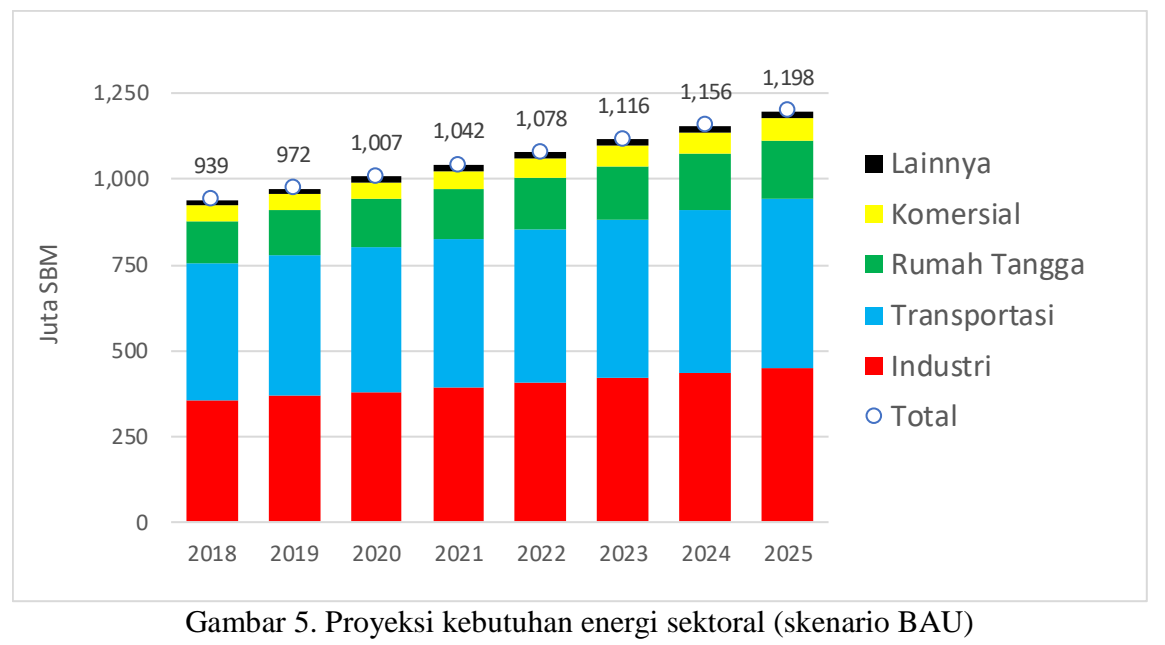

Secara umum proyeksi kebutuhan energi untuk skenario OPT, MOD, serta PES lebih kecil bila dibandingkan dengan skenario BAU. Proyeksi total penurunan kebutuhan energi untuk setiap skenario ditunjukkan pada Gambar 6. Pada tahun 2020, kebutuhan energi diperkirakan mengalami penurunan sebesar 10,7\% (skenario OPT), 15,3\% (skenario MOD), dan 20,0\% (skenario PES) jika dibandingkan dengan skenario BAU. Secara kuantitas mengalami penurunan sekitar 107,9 - 200,9 juta SBM. Pada tahun 2021 dan tahun-tahun selanjutnya, kebutuhan energi diperkirakan akan meningkat kembali seiring dengan selesainya pandemi. Lama waktu pemulihan tersebut bervariasi tergantung dari skenario. Semakin lama durasi PSBB, pemulihan akan semakin lambat dan semakin jauh dari jalur pertumbuhan sebelum krisis (skenario BAU). Untuk skenario MOD dan PES, kebutuhan energi tidak dapat pulih kembali seperti sebelum krisis (skenario BAU).

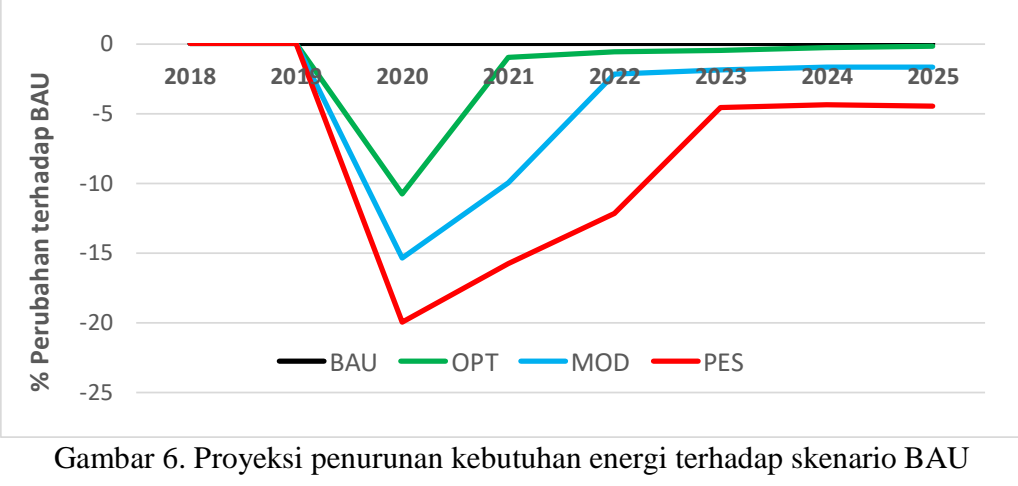

Dilihat dari sektor pengguna energi, komposisi penggunaan energi berdasarkan sektor pengguna tidak mengalami perubahan yang signifikan. Sektor transportasi merupakan sektor pengguna energi yang terbesar, kemudian diikuti oleh sektor industri, rumah tangga, komersial, dan sektor lainnya. Hampir semua sektor mengalami penurunan kebutuhan energi, kecuali sektor rumah tangga yang mengalami sedikit kenaikan karena efek WFH. Perbandingan proyeksi kebutuhan energi sektoral ditunjukkan pada Gambar 7. 


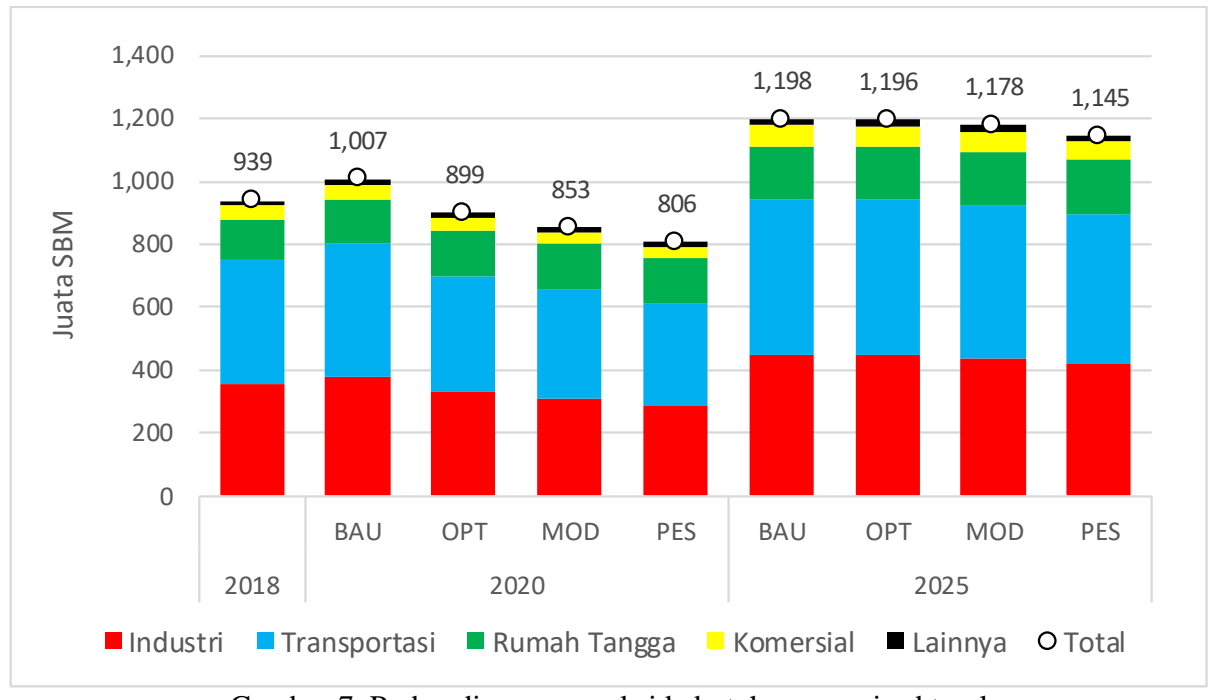

Gambar 7. Perbandingan proyeksi kebutuhan energi sektoral

Studi dari negara-negara lain juga menunjukkan bahwa pandemi COVID-19 akan menurunkan kebutuhan energi. Enerdata [22] memperkirakan bahwa pandemi di Perancis pada tahun 2020 akan menurunkan kebutuhan energi sebesar 4,6\% sampai $11,5 \%$ tergantung dari kurun waktu pembatasan sosial dan pemulihan ekonomi. Penurunan tersebut cukup besar bila dibandingkan dengan pada saat krisis ekonomi pada tahun 2009 yang kebutuhan energinya menurun sekitar 5,3\% dan pada saat krisis minyak pada tahun 1975 menurun sebesar 7,8\%. IEA [23] memproyeksikan bahwa kebutuhan energi di Amerika Serikat pada tahun 2020 menurun sebesar 6\% dibandingkan tahun sebelumnya karena dampak pandemi COVID-19.

\section{PENUTUP}

Kebijakan PSBB berupa pembatasan kegiatan masyarakat yang membatasi aktivitas ekonomi, pada akhirnya berdampak pada menurunnya kebutuhan energi. Penurunan kebutuhan energi akibat berkurangnya aktivitas ekonomi dimodelkan secara baik menggunakan perangkat lunak LEAP. Pemodelan energi menggunakan LEAP disusun berdasarkan data yang cukup rinci, meliputi: data sosial ekonomi, data energi, dan data aktivitas masyarakat karena adanya pembatasan sosial. Hasil model menunjukkan bahwa kebutuhan energi pada tahun 2020 mengalami penurunan sebesar 10,7\% (skenario OPT), 15,3\% (skenario MOD), dan 20,0\% (skenario PES), jika dibandingkan dengan skenario BAU.

Pemodelan energi yang dibuat dalam makalah ini lebih dimaksudkan untuk melihat beberapa kemungkinan yang akan terjadi di masa depan, dan masih memerlukan perbaikan lebih lanjut untuk melakukan prediksi masa depan yang lebih akurat. Ke depan model akan dikembangkan lebih lanjut untuk menganalisis dampak pandemi COVID-19, baik terhadap sisi kebutuhan maupun sisi penyediaan energi secara keseluruhan. Aspek lingkungan seperti dampak pandemi COVID-19 terhadap emisi GRK dapat juga dimodelkan menggunakan LEAP dengan menggunakan emisi faktor dari Intergovernmental Panel on Climate Change (IPCC).

\section{REFERENSI}

[1] PLN, Rencana Usaha Penyediaan Tenaga Listrik PT PLN (Persero) 2019-2028, PT PLN (Persero), 2019, Jakarta.

[2] Y. Petriella, "Konsumsi Listrik Berkurang, PLN Diprediksi Rugi Rp7 triliun", bisnis.com, 19 April 2020, diakses 20 April 2020.

[3] A. Umah, "Konsumsi Listrik Anjlok, Pendapatan PLN Bisa Turun Rp 44 T", CNBC Indonesia, 22 April 2020.

[4] R. Taviv, A. Trikam, T. Lane, K. O'Kennedy, M. Mapako and A.C. Brent, "Developing an environmental impact tool to assess energy scenarios at national level", South African National Energy Research Institute Pty, 2008. 
[5] J.A. Nieves, A.J. Aristizabal, I. Dyner, O. Baez, D.H. Ospina, "Energy demand and greenhouse gas emissions analysis in Colombia: A LEAP model application", Energy. 169 (2019) 380-397.

[6] N.V. Emodi, T. Chaiechi, and A.B.M.R.A. Beg, "Are emission reduction policies effective under climate change conditions? A backcasting and exploratory scenario approach using the LEAPOSeMOSYS Model”, Applied Energy, 236 (2019) 1183-1217.

[7] L. Suganthi and A.A. Samuel, "Energy models for demand forecasting - A review", Renewable and Sustainable Energy Reviews, 16 (2012) 1223- 1240.

[8] MEMR, Handbook of Energy and Economic Statistics of Indonesia 2018, Final Edition, Ministry of Energy and Mineral Resources, 2018, Jakarta.

[9] PLN, Statistik PLN 2018, PT PLN (Persero), 2019, Jakarta.

[10] Ditjen Gatrik, Statistik Ketenagalistrikan 2018, Direktorat Jenderal Ketenagalistrikan, 2019, Jakarta.

[11] BPS, Indonesia Statistics 2019, Central Bureau of Statistics, 2019, Jakarta.

[12] S. Mashabi, "Daftar 18 Daerah yang Terapkan PSBB, dari Jakarta hingga Makassar", nasional.kompas.com, 20-4-2020, diakses 19 Mei 2020.

[13] Google, "COVID-19 Community Mobility Report: Indonesia", April 2020, google.com/covid19/mobility, diakses 4 Mei 2020.

[14] Kemenkeu, "Program Pemulihan Ekonomi Nasional", Konferensi Pers 18 Mei 2020, Kementerian Keuangan, Jakarta.

[15] Word Bank, East Asia and Pacific in the Time of COVID-19, The World Bank, 2020, Washington, DC.

[16] A.A. Widyasanti, "Dampak COVID-19 terhadap Perekonomian: Saat Ini dan Masa Datang", Dipresentasikan pada Temu Alumni Teknik Kimia, 21 April 2020, ITB.

[17] L. Sheiner and K. Yilla, "The ABCs of the post-COVID economic recovery", May 4, 2020, www.brookings.edu, accessed May 30, 2020.

[18] P. Carlsson-Szlezak, M. Reeves and P. Swartz, "What Coronavirus Could Mean for the Global Economy", Harvard Business Review, March 3, 2020.

[19] P. Beech, 'Z, V or 'Nike swoosh' - what shape will the COVID-19 recession take?", World Economic Forum, May 19, 2020.

[20] E.Bekkers, A. Keck, R. Koopman and C. Nee, "Methodology for the WTO Trade Forecst of April 8 2020, Part I: Simulating Some Potential Economic Effects of the COVID-19 Pandemic", World Trade Organization, 2020.

[21] A. Wahid, "Saling Jaga", 12 April 2020, kompas.id, diakses 15 April 2020.

[22] Enerdata, "COVID-19: the drop in energy consumption in 2020 will be unprecedented", Analyst Brief - April 2020, Enerdata, Grenoble.

[23] IEA, Global Energy Review 2020: The impacts of the Covid-19 crisis on global energy demand and $\mathrm{CO}_{2}$ emissions, International Energy Agency, 2020, Paris. 